\title{
Miranda
}

Revue pluridisciplinaire du monde anglophone /

Multidisciplinary peer-reviewed journal on the English-

speaking world

$14 \mid 2017$

Early American Surrealisms, 1920-1940 / Parable Art

\section{Ritual and parable in Britten's Curlew River}

\section{Gilles Couderc}

\section{OpenEdition}

\section{Journals}

Electronic version

URL: http://journals.openedition.org/miranda/9897

DOI: $10.4000 /$ miranda.9897

ISSN: 2108-6559

\section{Publisher}

Université Toulouse - Jean Jaurès

\section{Electronic reference}

Gilles Couderc, "Ritual and parable in Britten's Curlew River", Miranda [Online], 14 | 2017, Online since 04 April 2017, connection on 16 February 2021. URL: http://journals.openedition.org/miranda/9897 ; DOI: https://doi.org/10.4000/miranda.9897

\section{This text was automatically generated on 16 February 2021.}

\section{c) (ㄱ) $\ominus$}

Miranda is licensed under a Creative Commons Attribution-NonCommercial-NoDerivatives 4.0 International License. 


\title{
Ritual and parable in Britten's Curlew River
}

\author{
Gilles Couderc
}

Opera, as the recreation of Greek tragedy combining singing, chanting and dancing, is linked to rites of death and fertility. The genre provides the staging of rituals like celebrations, processions, parades, oath-taking, church services, prayers or death as theatrical elements inserted in its dramaturgy. It has generated its own musical conventions and ritual musical forms, which obey strict aesthetic codes and practices. Britten was well aware of the ritual of musical forms in opera, and most of his twelve operas carefully stage a ritual of death including those forms. His self-definition as "a musician for an occasion" in his Aspen Award Speech of 1964 (Kildea 2003, 267) reflects his practice of, and participation to rituals like his 1939 Ballad of Heroes composed in memoriam the British volunteers in the Spanish Civil War, his Ceremony of Carols of 1942, the Cantata Academica of 1960 for the $500^{\text {th }}$ anniversary of Basle University or the Cantata Misericordium of 1963 for the Red Cross Centenary. His Aspen Award Speech spells out his belief that listeners should be prepared for music and make "some effort, a journey to a special place" beforehand (Kildea 2003, 261). His "holy triangle of composer, performer and listener" (Kildea 2003, 261), -when the listener is at one with the composer, "either as a performer himself, or as a listener in active sympathy" (Kildea 2003, 260) - led him to physically involve the audience in his works, as with the original "audience songs" of The Little Sweep of 1949 or with the traditional church hymns incorporated to Saint Nicolas of 1948 or to Noye's Fludde of 1958. They transform the audience "from silent witnesses to inhabitants of the symbolic world visible before them" as they coordinate a group "into one performing body" (Rupprecht 28). Though Britten's 1962 War Requiem does not include hymns for the audience, it is based on the ritual and liturgy of the Mass of the Dead. The force of suggestion of its ritual was increased as it was first performed in the newly dedicated Coventry Cathedral, rebuilt after the blitz of November 1940, as part of the dedication ceremonies, thus building a ritual-within-ritual pattern. 
Britten composed many pieces related to church ritual, like his two Te Deum or his 1959 Missa Brevis. He enjoyed a long relationship with Walter Hussey, who commissioned Britten's Rejoice the Lamb of 1943 and who, as Dean of Chichester, remained a staunch believer in the Anglican Church as patron of the arts. Raised by a Low Church mother, Britten was first exposed to plainsong and High Church Anglican ritual at Gresham's School (Mitchell and Reed 93-95) and subsequently developed a keen interest in plainsong (Elliot 44-73). Appreciating church architecture was part of his artistic education with his master Frank Bridge and his letters from his beloved Venice abound in descriptions of its churches, their riches and ceremonies. For very practical reasons, the local Suffolk churches of neighbouring villages provided venues for his Aldeburgh Festival concerts, especially the Norman and Gothic churches of Orford and Blythburgh. The former was first used for the 1958 Noye's Fludde performances. The latter, dedicated to the Holy Trinity, is known as the "Cathedral of the Marshes" and famous for the great coloured angels with outstretched wings embossed in the nave's roof. The churches became favourite concert venues closely associated to Britten's "holy triangle", to his conception of listeners as pilgrims and to his love of their generous resonant acoustic, the "Gothic sound", rewarding for both performers and listeners, when the reverberation of a single note "produces a string of notes together, its own form of harmony" (Kildea 2003, 294), itself a form of heterophony.

In that context, his letter of April 2, 1964, to his librettist, the poet and novelist William Plomer (1903-1973) comes only as a mild shock as, barely three months before the first performance of their new operatic adventure, their adaptation of the fifteenth-century Japanese Noh play, Sumidagawa or Sumida River, by Jūrō Motomasa (1395-1431), Britten tells Plomer that it will be called Curlew River, a parable for church performance, a title fraught with meaning (Reed and Cooke 580). Sumida River stages the story of a demented woman in search of her abducted son who finally discovers his grave and mourns after a ferryman agrees to take her across the river. The new title made it clear that the new piece was not an opera in the accepted sense and that it must be done in a church, a venue that would bring performers and listeners in close contact: it would provide the equivalent of the Noh auditorium, where the stage and its roof project into the audience, embracing actors and audience alike. Plomer wholeheartedly supported the parable idea and provided Britten with definitions of the genre as "an earthly story with a heavenly meaning" or a "fictitious narrative used to typify moral or spiritual relations", which all tallied with their new work (Reed and Cooke 579). Plomer had worked on its libretto since 1958, two years after the composer had seen the Noh play in Japan, on the advice of Plomer himself, during a Far East trip. Plomer had long lived in Japan in the 1920s and was enthralled by its culture and Britten had been interested in Noh and Japanese theatrical arts, purchasing a copy of Ezra Pound's Noh translations published by Faber in 1953 (Cooke 24-25, 141). Britten was so impressed by the simplicity of the story and the strangeness of the performance that he saw the play twice:

The whole occasion made a tremendous impression upon me: the simple touching story, the economy of style, the intense slowness of the action, the marvellous skill and control of the performers, the beautiful costumes, the mixture of chanting, speech, singing which, with the three instruments, made up the strange music - it all offered a totally new "operatic" experience (Britten, A Note by the Composer, Decca Recording SET 301, London: Decca, 1965). 
In a broadcast message to Japan of 1958 Britten further commented on the profound impact of the Noh play: "The deep solemnity and selflessness of the acting, the perfect shaping of the drama (like a great Greek tragedy) coupled with the strength and the universality of the stories are something which every Western artist can learn from" (Cooke 120). Britten then asked Plomer to adapt the play's official translation into a libretto. ${ }^{1}$ But in April 1959, much to Plomer's surprise and relief, Britten asked him to christianize the secular story as its "little bits of Zen-Buddhism" (Reed and Cooke 130) did not mean much to him and might not mean anything to its audiences to whom he feared the work might appear as a pastiche or some sort of "Japoniaiserie" (Reed and Cooke 580), as if he was wary of any associations with Gilbert \& Sullivan's 1885 comic opera The Mikado, a satire of British politics and institutions ${ }^{2}$. Britten later spelt out why: the wonderful experience "visually, dramatically and acoustically" of performing Noye's Fludde in Orford Church, and his wish to turn the story into a "monastic drama" performed by men and boys (Reed and Cooke 151). Britten had immersed himself in medieval religious drama and mystery plays in England since his setting to music two Chester Miracle Plays, Abraham and Isaac in 1952 and Noye's Fludde in $1958 .^{3}$ His interest in medieval drama reflected the British revival of mystery and miracle plays initiated in the 1920's and reaching its peak in the 1950's with the triennial York Festival, founded in $1951^{4}$. He had looked for a Medieval Latin poem that dramatised the parable of the Good Samaritan for his 1963 Cantata Misericordium before he asked the Cambridge Latin scholar Patrick Wilkinson to dramatize it in Latin (Reed and Cooke 397). Relocating the Noh play in a Fenland church, possibly in pre-Conquest times, acted out by a community of monks, made it possible for his companion Peter Pears to sing the role of the Madwoman. In this version, departing from the Japanese original yet in keeping with the intrusion of the supernatural common to Noh plays (Murray 60), the twelve-year old boy, having now become some local saint after his premature death, finally appears spirit-like to his mother and grants her the peace she has been seeking as a sign of God's grace.

5 Plomer had known Britten for many years and the parable idea must have been no surprise as many of Britten's operas, from the Brecht-influenced Paul Bunyan of 1941 to his recent Midsummer Night's Dream of 1960, set out to deliver a message, in a more or less explicit fashion (Couderc 2004). Thus the Male and Female Chorus of the 1946 Rape of Lucretia harness a Christian interpretation to the age-old Roman story. Captain Vere in his Prologue to Britten's 1951 Billy Budd clearly underlines in quasi-Goethean fashion the opera's metaphysical stakes, the ubiquity of evil in the divine creation while his epilogue celebrates love, forgiveness and redemption. The Offertorium of Britten's 1962 War Requiem set to music Wilfrid Owen's bitingly ironic reworking of the story of Abraham and Isaac in the "Parable of the Old man and the Young", allowing Britten the pacifist to parody his own 1952 setting of the Chester Miracle Play in his denunciation of war-mongering, while Cantata Misericordium, a dramatisation of Luke's Good Samaritan parable, focused on the practice of compassion. Moreover, thanks to his close collaboration with the poet on GPO Films in 1935-1936 as musical director and on his Group Theatre plays, Britten belonged to the "Auden Generation" who believed that literature and poetry were forms of action. In 'Psychology and Art To-day' (1935) Auden defined parable-art as "that art which shall teach man to unlearn hatred and learn love" (Hynes 169), the ferment of change whose main agents would be art and artists, a concept to which Britten adhered all his life. ${ }^{5}$ In his operas Britten also made his own 
the words of Auden in his Preface to The Poet's Tongue of 1935 which also provided another definition of parable-art, well removed from propaganda:

Poetry is not concerned with telling people what to do but with extending our knowledge of good and evil, perhaps making the necessity of action more urgent and its nature more clear, but only leading us to the point where it is possible for us to make a rational and moral choice (Hynes 14).

The "Auden Generation" featured the poet Louis MacNeice, an associate of Britten's in the thirties and forties and of Auden's in the thirties. ${ }^{6} \mathrm{He}$ had given his Cambridge Clark Lectures of 1963 published under the title of Varieties of Parables. While they outline the poet's own poetics a few months before his death, they also define and illustrate the significance of "parable" for the times in which he lived, in a discussion that makes use of the literary criticism of the time and ranges widely from Spenser's Faerie Queene and Bunyan's Pilgrim's Progress to writers to whom MacNeice felt very close, Samuel Beckett, Harold Pinter and William Golding. Nothing says that Britten was aware of MacNeice's lectures, or of the contemporary writers quoted, yet we find the coincidence of the poet's summing up and the musician's start on a new aesthetic venture intriguing. ${ }^{7}$ We shall examine Britten's first church parable with the tools that MacNeice provides in his analysis of 'parable' and concentrate on the interconnection of parable and ritual, in the libretto and the music, for the creation of a ritual of despair and redemption.

\section{Projecting a private world}

7 MacNeice suggests that "any parable writer [...] is concerned with the projection of a special world" which may be a private world especially when the author is dealing with man the solitary animal, "the better to regain communion with his fellows" (MacNeice 28). This chimes with Britten's concept of the local as a way to reach the universal:

And in my own small experience I have learned that if one concentrates on the local, the particular, if one writes for particular singers, instrumentalists, local occasions, the works can have an actuality, a realistic quality, which can make the result useful to the outside world. (Kildea 209)

The venue for the first Curlew River, Orford's Norman Church, was itself part of Britten's private world, his beloved Suffolk, only a few miles down the river Alde. Rising at the top of the village street and set amid a wide space, the church dominates the former medieval town tucked away across the wide river near the North Sea, a double symbol of isolation.

9 The parable opens and closes with the prologue and epilogue of the Abbot's company of monks and instrumentalists walking in a procession to, and later leaving the acting area, singing the plainsong hymn Te lucis ante terminum. The procedure, borrowed from Britten's 1942 Ceremony of Carols and used in the recent Cantata Misericordium, also recalls the unfolding and folding of the stage backcloth by the musicians at the beginning and end of Noh plays (Coldiron 133). While it provides a framework that removes the audience from their mundane daily concerns and suspends disbelief, the prologue asserts the Abbot's moral authority, all the more so as, after a flourish of drums and of the chamber organ whose sound evokes ritual, he appeals to them as members of a congregation, "good souls" or "beloved". Moreover, the audience are constantly reminded of their being the witnesses of a rite either by the monks, as "souls akin to you", or by the Ferryman, "Mark this well all of you". This framework 
sets the parable in the "allegorical tradition of the medieval pulpit" continued by the tradition of the sermon in the village church illustrated among others by Bunyan's Pilgrim's Progress (MacNeice 43) while it sets up the audience as potential apostles.

The play-within-the play structure of the work, with the Abbot calling the story of the Madwoman "our mystery", which links it with medieval drama, is emphasized by the quadruple frame of the prologue including successively the Gregorian hymn, the Abbot's address with the triple response "A sign of God's grace", the monks' ensemble "O pray for the souls of all that fall", and the robing and disrobing ceremonies, inspired by a celebration of Mass at Venice's San Giorgio Maggiore (Reed and Cooke 563), the latter to a heterophonic instrumental fantasy based on the opening hymn, with the whole sequence in inverse order in the epilogue. That quadruple frame creates a distance and establishes a convention of performance, far removed from traditional opera and closer to liturgy. The sense of a ritual, inspired by the Noh's coded gestures and stylized dancing, was developed and minutely described in the Production Notes written up by Colin Graham, the director of the original production and included in the Rehearsal Score published by Faber. ${ }^{8}$ Limiting what Graham calls the "miming" to spare, economical gestures, drew attention to each of them, loaded with meaning: "Every movement of the hand or tilt of the head should assume intense meaning and, although formalised, must be designed and executed with the utmost intensity" (CRRS). Britten was involved in every facet of the staging and fine-tuned the music to the acting: Graham notes that "final details of the music were worked our simultaneously with the dramatic ideas (Cooke 154)". Thus the spare musical material echoed the spare miming.

11 Just as Noye presented the action on a rostrum, and not a stage removed from the congregation, with the instrumentalists clearly on view, the first performers of Curlew River accessed the main circular stage by a ramp that gradually rose from the audience level. A special raised smaller circular acting area, off-centre, was reserved to the main protagonists of the mystery, the Ferryman, the Traveller and the Madwoman, while the instrumental soloists sat facing the audience on the other side. The parable's chamber orchestra of flute, horn, double bass, viola, percussion, harp and chamber organ clearly evoked Noh sounds (CRRS). All three principals wore half-masks indicating their character and status', which further removed them from theatrical realism and emphasized their being the denizens of a private world. Their costumes exposed the hems of their monk's habits, never letting the audience forget they were watching the performers of a ritual included in the ritual of a work of art.

Ritual includes physical deeds or gestures as well as words. Even though Plomer amply borrowed from the Noh original, Britten insisted on using words that would resonate in European minds, like "land" and "kingdom" as well as that of "river folk" instead of "village" to emphasize the historical remove to his unspecified pre-conquest times or place: "(We might even set it "no-where", with the "river", "the village", etc.)" (Reed and Cooke 131, 558). Contrary to Noh tradition (Cooke 150), the Abbot and the monks as Pilgrims sketchily but suggestively map out the private world of the mystery, a landscape very familiar to Britten, that of the reedy Fenland, whose dyke-intersected marshes, "dyke, marsh and mere, the land of the Eastern Fens", extend well into Suffolk. Moreover, the horn flourishes that introduce and characterize the Ferryman suggest the wilderness of desolate places traditionally associated with curlews in Celtic lore. Referred to as the "Holy Land of the English" on account of its numerous monastic 
foundations and the great cathedrals of Ely and Peterborough, the Fens provided many of the shrines or chapels near which the abducted boy dies, like the shrine of our Lady of Walsingham in nearby Norfolk established in 1061: "But we might get a very strong atmosphere (which I personally love) if we set in in pre-conquest East Anglia where there were shrines galore."(Reed and Cooke 131). The Traveller and the Madwoman both conjure a mist-covered landscape of heaths, pastures, woods and moorland where danger lurks, in the shape of drovers and foreign pagan slave drivers, which gives the mystery a Pilgrim's Progress (and Lord of the Rings) feel which recalls Viator, the Traveller in Cantata Misericordium, expressing his fears: "Ah quam longa est haec via".

\section{“Divided asunder": separation's many faces}

The "glassy" Curlew River, whose still waters run deep, establishes a clear-cut division between the flat marshy Fens of the East and the kingdom of the West and the Black Mountains from which both Madwoman and Traveller originate. The Black Mountains in the Western Marches that the Ferryman mentions may obliquely refer to the hills of Southern Wales, intersected by Offa's Dyke, which separated the Anglian Kingdom of Mercia from that of Welsh Powys, thus expanding further the theme of separation present in many guises in the mystery. Both chorus and Ferryman, a Charon-like figure, establish the river as agent or symbol of separation as central to the parable. ${ }^{10}$ Supported by the organ and evoking the ripples of the lapping waters, the monks' chorus first introduces the motif of the river separating the two kingdoms after the Ferryman's entrance and the motif is taken up six times in all, four times in its original guise (Figs. 9, 18, 38 and 79), thus establishing the materiality of the river. The Ferryman insists on its width, its strong currents beneath its glassy surface and the reeds that make it difficult to navigate, invoking God's help for their crossing. Later on, his long prose narration of the Boy's story transmutes in time the width of the river as obstacle, echoing Wagner's Gurnemanz's "Here space and time are one" to Parsifal at the end of Act I, scene $1^{11}$. The emphasis on the river as a boundary also prepares the intrusion of the supernatural as MacNeice recalls: "boundaries between territories, like boundaries between years and between seasons, are lines along which the supernatural intrudes through the surface of existence." (MacNeice 99) The river then also proves to be a symbol of union as the chorus indicates before Fig. 57 : "Ah Ferryman, Row your ferryboat, Bring nearer, nearer, Person to person, by chance or misfortune, Time, death or misfortune, Divided asunder!" The crossing of the river, with all the mystery's characters huddling in the small boat, is signalled as being out of time and nowhere, as it opens and closes with the repeat of the monk's Curlew River chorus. It is the first step towards the final redemption: the three principals are now brought together as the Ferryman narrates the death of the Boy saint, and the Madwoman reveals herself as a noble woman with a noble purpose, "she knows what she seeks", thus indicating there might be some reason in her madness, a first step towards understanding and acceptance.

The river image mutates into the motif of yearning, longing and physical separation, introduced by the Madwoman as she steps on stage and asks "Where is my darling now?" The chorus expands the theme with "A thousand league may sunder a mother and her son" at the end of the Madwoman's first narrative "Near the Black mountains There I dwelt". It is later varied and expanded, along with the river motif in the Curlew 
River ensemble at Fig. 56 before the Ferryman's narration and then again at Fig. 69, when the Traveller, Abbot and Pilgrims leave the boat. The theme is given a further twist with the mysterious Riddle of the Famous Traveller quoted by the Madwoman ("Tell me, does the one I love In this world still live?") after she renames "curlews" the birds flying over her head, thinking her son has flown away with them. The riddle is taken up by the Traveller and this develops as the great "Tell me, does the one I love" ensemble, where the voices are dominated by the yearning motif of the flute associated, Lucia-like ${ }^{12}$, to the Madwoman. She takes up the riddle a last time, accompanied by the flute, just before the voice of the Spirit is heard as an answer to her frantic questions. The Boy slowly and silently circles round his mother accompanied by a piccolo that indicates their kinship, before giving his mother his blessing.

The Madwoman introduces a further variation on the separation motif, that of madness as divided self, with her second riddle at Fig. 24 before she finally appears on stage: "Why the point of an arrow Divideth the day? Why to live is to warm An image of clay Dark as the day?" This is set to the same descending musical phrase as "Where the nest of the curlew Is not filled with snow, Here the eyes of the lamb Are untorn by the crow". Accompanied by the viola's repeated major seventh chords, it paints the image of her fractured self and disharmony with the world around her, itself a riddle for her confused mind. Hence the three riddles mentioned, akin to the three enigmas of traditional tales, two of which here remain unsolved. The Madwoman takes up the "nest of the curlew" motif, now in a retrograde fashion which indicates her being walled in by grief, as she realises her long-lost child is dead, in the renewed outburst of frenzy in her "O Curlew River, cruel Curlew" monologue at Fig. 76. These very simple examples of madrigalism, inherited from Monteverdi or Bach, abound in Britten's music. They also belong to the "parable ethos", where simple, everyday elements provide the basics of its narratives and simple images illustrate meaning.

Another image of fractured self is the "You mock me, You ask me" motif at Fig. 20 when she is first heard, then the more transparent "Let me in, Let me out" at Fig. 21, which later on becomes the cry of the curlew at Fig. 89. While it adopts the sliding vocal gestures of Noh, the motif is all the more arresting as the Ferryman and the Traveller introduce themselves in the assertive fashion, "I am the Ferryman" or "I come from the Westland", that recalls the directness of morality plays. Though nothing more than an addition of unequal fourths as Peter Evans indicates (Evans 474), the Madwoman's motif springs at you from the score's printed page as the image of the Madwoman literally pulled apart in opposite directions and it generates a series of fourth-based melodic fragments that recall the dilemmas of the Governess in Britten's Turn of the Screw and Britten's almost ritualistic use of that particular musical interval, foreign to the perfect triads of the tonal system (Couderc 251) ${ }^{13}$. Here those medieval-sounding fourths, and their ambiguous harmonic, organum-like, implications, simply illustrate the woman's alien status. ${ }^{14}$ One last image of fragmented self in the "Near the Black Mountains" monologue is the oxymoronic simile "With silence ev'ry room was full, Full of his absence, Roaring like the sea" before Fig. 35, taken up later by the chorus before Fig. 87 as "Deafened by his silence, Roaring like the sea", in the same monotone as for its first appearance, thus expressing utter despair.

17 As MacNeice recalls "the concord of unlikes" belongs to the allegorical tradition (MacNeice 50) and "the presentation of Man's soul as a lady in distress was as familiar in the Middle Ages as the fact that grass is green (MacNeice 31)". The Madwoman 
stands for "the fallen, the lost and the least" described in the monks' exhortation of the Prologue. Her anguish over the disappearance of her darling and her clawing helplessly at the tomb, and eventual sinking down in tears, recalls that of a figure given much prominence in Medieval times and early Baroque painting, poetry and music, Mary Magdalene who, according to the Gospel of John $(20,11-16)$ stoops down, and looks into the empty sepulchre on Easter morning before being comforted by Christ just risen from his grave, the "Noli me tangere" scene so prominent in painting. Nothing says that Plomer or Britten were actually aware of the connection but Britten's many stays in Venice confronted him with many of those Maddalena a piè della Croce paintings, the Magdalene at the foot of the Cross that Colin Graham's Production notes depict (CRRS Fig198), with the Boy's tomb as a miniature Golgotha. The Magdalene/Easter story may provide listeners with a prescriptive subtext, easy to follow, and lead them to associate the parable with the rituals of Passiontide, very familiar to Peter Pears who collaborated to the writing of the parable, as he often sang the role of the Evangelist in Bach's St John's Passion, which Britten often conducted (Reed, Cooke and Mitchell 514).

\section{Repetition, despair and redemption}

What is striking so far is the number of repetitions we have underlined. As MacNeice recalls (MacNeice 4), in a long work, to make any impact, an image or a number of poetic images of the same type must recur. Ritual is founded on repetition and Curlew River uses repetition to build up its own ritual. Plomer's use of short lines, often repeated, and of short forms, haiku-like as in "Dew on the grass Sparkles like hope And then is gone", contributes to the building up of a dream-like atmosphere, akin to that of allegory. Britten's widespread use of heterophony, when the notes of a melodic fragment provides its harmonies, results in a harmonic halo -hence the prominent use of the organ and harp here-, and also contributes to that dream-like atmosphere. Heterophony is given a further twist in Curlew River as singers sometimes repeat the same fragment out of sync with others or instrumentalists are sometimes requested to repeat parts that are not metrically synchronised until one performer has completed a given passage before proceeding, hence the invention of the curlew pause sign, ${ }^{\wedge}$ so as to create what Britten calls "controlled floating" (Reed and Cooke 552).

Repetition is necessary as musical motifs only make sense to listeners if they are repeated. Repetition also allows for the cohesion of otherwise disparate fragments: in Curlew River Britten forgoes the traditional operatic forms that listeners might identify and Plomer and Britten often proceed through textual and musical recapitulations, as indicated above, foreign to Noh conventions, but the better to achieve a sense of completion and of structural balance more comprehensible to Western audiences (Cooke 152). For example the story of the Boy Saint is first sketchily told by the Ferryman when he first appears; "Today is an important day" and completed by the Mother during her "Near the Black Mountains" monologue. It is extensively told during his prose narration, which he opens with the same prologue, while he navigates across the river and soberly reveals the full horror of the child who died like a man. The Ferryman repeats the story a third time to the Madwoman as he urges her to disembark, allowing the pilgrims to connect the Boy and his demented mother, plunging her deeper in despair: "He was the child Sought by this madwoman". The Boy's story thus provides the mystery with the architecture of a triptych. While this 
follows the ternary pattern common to Noh plays and to Jesus' parables (Miller 195-6), the Ferryman's narration acts as an axis of symmetry around which Britten organises the different monologues in which the Madwoman voices her despair, thus creating mirror images, as she moves from a figure of fun to an object of pity, and to acceptance. This provides unity to a linear narrative but also depicts the Madwoman's solitary confinement in her grief through those repetitions.

The Madwoman does indeed often repeat herself. She either repeats long musical sequences, as shown before, or she repeats simple words, as when she is first heard at Fig. 20 "Whither I, whither I go" or "How should I, how should I, how should I know?" or at Fig. 22 "Tell me the, tell me the way" or at Fig. 23 "How can you, how can you, how can you say?", or at Fig. 25 "I turn me, I turn me, I turn me away", a disjointed mode of utterance that conveys her losing her sense of direction and explains her rambling. But it is perilously close to opera buffa and Offenbach's "Bu qui s'avance" and, inevitably, it provokes the derisive laughter of the Pilgrims and leads them to command the Madwoman to sing for her to be allowed into the boat. On the other hand, repetitions build up the hopeless monotone of the "Next the Black Mountains There I dwelt". Here the reiterated sextuplets of quavers of the instruments are echoed by the Madwoman's voice, then progressively augmented to quintuplets of crochets in a slower tempo to emphasize the stasis of hopeless longing and utter despair from which there seems to be no escape, if we believe her "Hoping I wandered on" monologue at Fig 81, the diffracted mirror image of the "Near the Black Mountain" monologue. At this point the tenor's voice plunges to its lowest register, as if into a pit of darkness. It is as if the Mother had been cast in the dark dungeon of Doubting Castle, the lair of Giant Despair and his wife Diffidence in Pilgrim's Progress and, as Bunyan reminds us, despair is a sin against God. It is also the sin that the two enemy soldiers are caused to commit by the warmongers in Britten's War Requiem.

21 As Cooke remarks, the Mother makes no reference whatsoever to God and finds herself totally unable to pray until she joins in the final verse of the Custodes hominum hymn and is freed from her madness by the apparition of her son (Cooke 152). Her utter despair is first contrasted with the Ferryman's attitude and above all, the Traveller's behaviour. Her kinship with the latter is established from the start as he too comes from the Westland on a compelling, mysterious, dangerous and exhausting journey North, suggested by the trudging double bass and harp accompaniment when he first appears. He also seems on a quest, looking for a lost lady love perhaps, as he indicates in the "Tell me, does the one I love?" ensemble, which says he's known the taste of tears. But he acts as a foil to the Mother as he invokes God's help on his journey, decides to remain at the Boy Saint's tomb for worship and, with the Ferryman, he urges her to pray "Lady, remember, All of us here May pray for your child: But your prayer is best To rejoice his young soul." As fellow travellers they are the Horatios to the Mother's Hamlet or the Hopeful and Faithful to Bunyan's Christian.

The Traveller and the Ferryman are thus linked to the parable's ritual of prayer and redemption. It borrows from established liturgies, couched in the age-old language of the Church, thus establishing, like the Abbot's preliminary address, the authority of prescriptive texts, embedding prayer within the mystery. The Te lucis hymn, a prayer to be spared the terrors of the night and to obtain spiritual peace, sets up, with the triple repetition of the Gregorian tune, a ternary pattern common to Christian liturgy, which often associates the figure 3 with God. The Te lucis melody itself insists on thirds rather 
than on fourths and, as Peter Evans indicates, "its influence can be detected in almost every section of the work and is always strongest when Christian overtones are touched on" (Evans 472). The hymn Custodes hominum, which provides a parallel to the opening Te lucis and further stitches together the Prologue framework and the mystery, invokes the Holy Trinity, "Sanctae sit Triadi". The three stanzas of the Abbot's address in the Prologue include the three responses "A sign of God's grace". The prayer of the dying Boy "Kyrie Eleison", which belongs to the liturgy of forgiveness of the Mass, also implies a ternary pattern, and that sequence is completed by the Ferryman's and Traveller's "Christ have mercy upon us" as they pray before the Boy's tomb. The Litany that completes their joint prayer "All angels pray for us, All martyrs pray for us, All saints pray for us" also adopts that ternary pattern, and so does the Madwoman's final "Amen". Three, as the symbol of divine unity is thus constantly opposed to the unequal fourths associated with the Mother's fractured self. Here, one is reminded of Britten's playing with symbolic intervals, like his opposing Tarquinius's tetrachord to Lucretia's third-based motif in his Rape of Lucretia or Claggart's fourths to Vere's fifths and Billy's thirds in Billy Budd, probably one of his most powerful parable operas.

The steps of the ritual of redemption through prayer and the final "miracle" are clearly indicated and follow that same ternary pattern. It is initiated by an Acolyte tolling the big bell at Fig. 86, a manifest call to prayer and the sound of the bell punctuates the Ferryman and the Traveller's urging the Mother to pray. Next, the tintinnabulations of the small bells at Fig. 87 imply that some heavenly visitation or some epiphany is at hand, like in the Catholic ritual of consecration when the bread wafer and the wine on the altar become Christ's flesh and blood. This is confirmed by the chorus's quatrain "The moon has risen The river breeze is blowing The Curlew River Is flowing to the sea Now it is night And time to pray". It implies that the light of the Spirit is shining through the darkness and that the energy of the Holy Spirit, the Great Comforter, under the guise of the breeze and the now freely flowing water, is at play, an echo of the Gregorian chant 'Veni creator spiritus'. ${ }^{15}$ This is echoed by the Mother's "I pray with the others Under the light of the cloudless moon" as she joins in with the Ferryman and the Traveller before Fig. 88. All instruments and singers then combine for the "Custodes hominum" ensemble at Fig. 88. The return to Gregorian and Latin, from which Ferryman and Traveller and the Mother are first excluded, signals the shift from drama to liturgy, while the intrusion of English, with Owen's first poem, signalled the move from liturgy to drama in the War Requiem's Introit. As the Mother joins in the hymn for the climax of the ensemble at Fig. 90, the voice of the Spirit, a solo treble, is heard in the tomb as he repeats his mother's "Sanctae sit Triadi" in an echo. The effect, with the soprano range of the boy contrasting with the mostly lower ranges of the chorus is as miraculous as the treble's soaring above the monotone of the men's voices in Allegri's Miserere. When the Mother and the chorus realise they have heard her son's voice between Fig. 91 and 93, the audience's relation to the action suddenly change: they listen and see with the protagonists the Spirit appear in full view above the tomb, placing them on the same plane as the protagonists (Rupprecht 240). The Spirit circles round his mother, whom he blesses with the pilgrims to the same monotone as his Mother's with its characteristic end-of-line fall, another sign of their kinship. She bows her head, disappears behind the Pilgrims and a shortened reprise of the robing music brings the parable to its epilogue. 


\section{Epilogue}

24 Colin Graham's Notes indicate that "no lights should be turned on in the church at the end of the piece until an appreciable pause", thus giving time for the audience to meditate and ponder the mystery in the semi-darkness, in keeping with Britten's almost constant inclusion of epilogues in his operas (Couderc 2004). What is striking is how successfully the Christianisation of the Noh play works despite Plomer's ample borrowings from the original translation and how the "Zen-Buddhist bits" were given a Western flavour, more familiar to Britten and his audiences, including the change from the Japanese pine tree as a symbol of grief to the more familiar yew tree of Western poetry. This is Britten's way of joining East and West and of aiming at universality, as the special stage set devised for the parable indicates, with its circular stage akin to the Orbis Terrarum or Mappa Mundi of Medieval times. If Graham's Notes today sound pedantic and self-important to some (Kildea 2013, 467) and modern producers ignore Britten's masks, such stylised gestures have become the trademark of producer Bob Wilson in his attempt to emphasize the role of ritual through language and movement in his opera productions. Can we connect Britten's interest in religious drama with contemporary playwrights like Beckett and Pinter, whose work for MacNeice was a "return to the original, religious function of the theatre" as "these playwrights use the theatre in the way the Church used ritual" (MacNeice 15)? Britten's reference to "the deep solemnity and selflessness of the acting, the perfect shaping of the drama (like a great Greek tragedy)" when describing his reactions to Noh may point this way and so does Plomer's and Britten's awareness of Yeats' and Ezra Pound's interest in Noh and their wish to renew the language of the stage.

Curlew River certainly points back to the parable tradition of Pilgrim's Progress with the double quest of the Traveller and the Mother, and to the great English tradition of sacred music and oratorio to which the War Requiem gave a bitter twist. But it also points back to some of Britten's previous parables and the various meanings each may offer. Contrary to Peter Grimes, considered as a madman whose gradual exclusion from the community of the village is show through a series of emblematic scenes of social ritual,-the "Good morning" ceremonies, the round in the pub and the yearly dance at the Moot Hall-, the Madwoman is finally integrated in the community of the boat, a likely symbol for society and the Church, through the intercession of the Traveller and the Pilgrims, since "she knows what she seeks". Similarly, she is integrated in the community of the believers through personal prayer and a process of mutual understanding, she learning of her son's whereabouts from the Ferryman who eventually comes to accept her in his boat once he has understood her quest. As Wiebe indicates, the process of learning from an encounter with the unknown or the Other is part and parcel of the parable genre (Wiebe 2013, 169), and it recalls the déclassé Samaritan's encounter with the Traveller of strict Jewish observance in Britten's Cantata Misericordium. Yet the Madwoman's boarding the boat is only procured through her singing, amid the derisive laughter of the Pilgrims, which may be read as a means for Britten to voice his anguish, already sounded in Paul Bunyan or in Peter Grimes, about the place of the artist in modern society or, for that matter, about his place (and Pears's) as a homosexual in the community. ${ }^{16}$ The viola was Britten's instrument when playing in a string quartet and its major sevenths underpinning the Madwoman's riddles then afford a very personal meaning. ${ }^{17}$ The issue of the place of the artist, and of 
the musician in society, Britten took up again in his Aspen Award speech of July 1964, barely a month after the first performance of Curlew River. He quotes an anecdote of his youth, where his career plans as a composer were met by a scathing "Yes, but what else?" and then articulates the mild view that the artist shall be accepted as an essential part of human activity and of value to the community (Kildea 2003, 258-9). As a figure of exclusion, finally accepted into the mainstream, the Mother rapidly disappears behind the Pilgrims, with no clear indication of her fate, in an ambiguous ending. Her plight also reflects Britten's own struggles for humanitarian and pacifist ideals as they are expressed in his occasional works as well as in his operas.

Contrary to Britten's operas where children's innocence is abused, Peter Grimes, The Little Sweep or the Turn of the Screw, the child here is an agent of redemption and the mother redeemed, an exception in Britten's gallery of rogue parents, further extended in his 1965 Songs and Proverbs of William Blake, which incorporate some of the poet's most violent denunciation of the Church and of dogma-manacled parenthood, London and The Chimney Sweeper. Yet, as Wiebe remarks, if Noye was joyfully eclectic, humorous and boisterously communal, a romp for children performers that insisted in the full presence of the divine, Curlew River uses ritual and the medieval as exotic and remote (pace the pre-Conquest times) and involves a brief glimpse of the very abstract Holy Spirit "to offer a very different vision of redemption, as purity and austerity, as distantly abstract, as fundamentally individual" (Wiebe 190). With the pruning of Shakespeare's first act, Britten's 1960 Midsummer Night's Dream hardly leaves Oberon's wood, isolating the play's characters in the Fairy King's demesne. Between the completion of Noye and Curlew River Britten composed his War Requiem which grants eternal peace to the two soldiers isolated in the tiny world of the chamber orchestra and then only very reluctantly to the Latin-singing choir standing for the anonymous crowd of mourners. Cantata Misericordium also delivers a message of one-to-one redemption through compassion. Can we see there the expression of Britten's growing pessimism in the face of contemporary events, the Cold War and its dire consequences, despite his holding on to his parable-art principles? After the River, Britten was to write two other Church parables, thus removing himself further from the world of opera until the 1970's. Curlew River is also the story of Britten's gradual self-imposed isolation from the world of large cities and his entrenchment in the microcosm of Aldeburgh, its festival and the newly opened Snape Maltings, as a respite from a busy international career. The worldwide success of his War Requiem also unsettled him, caused him to doubt his powers of musical invention as well as his status as a composer and sent him on a quest for new musical approaches and partnerships, as exemplified by his return to the highly private and rarefied world of chamber music with the three Cello Suites written for his great friend Slava Rostropovitch (Couderc 2006). ${ }^{18}$

\section{BIBLIOGRAPHY}

Britten, Benjamin. Curlew River: Rehearsal Score, (CRRS). London: Faber Music, 1966. 
---. A Note by the Composer, Decca Recording SET 301, London: Decca, 1965.

Coldiron, Margaret. Trance and Transformation of the Actor in Japanese Noh and in Balinese MaskedDance Drama. New York: The Edwin Mellon Press, 2004.

Cooke, Mervyn. Britten and the Far East, Asian influences in the music of Benjamin Britten. Aldeburgh Studies in Music, Vol. 4. Woodbridge: The Boydell Press, 1998.

Couderc, Gilles. Britten et l'art de la parabole. La Revue Lisa/Lisa e-journal, Vol. II, n³, 2004, http:// lisa.revues.org, visited on March 27,2017

---.«Britten et les Russes, itinéraires croisés ». Slavica Occitania n²3, Accords majeurs, les échanges musicaux entre la Russie et le monde (XIX-XX siècles). Toulouse, 2006, 91-106

---. «Quatre et quartes, le diable est à quatre chez Britten : fantastique et images du mal dans The Turn of the Screw". Opéra et fantastique. Lacombe, Hervé \& Timothée, Picard, (eds.). Rennes: Presses Universitaires de Rennes, 2011, 241-53.

Elliot, Graham. Benjamin Britten, The Spiritual Dimension, Oxford: O.U.P., 2006.

Evans, Peter. The Music of Benjamin Britten, London: Dent, 1979.

Hynes, Samuel. The Auden Generation, Literature and Politics in England in the 1930s, London: Pimlico, 1992.

Kildea, Paul (ed.), Britten on Music. Oxford: Oxford University Press, 2003

---. Benjamin Britten, a Life in the Twentieth Century. London: Allen Lane, 2013,

MacNeice, Louis. Varieties of Parables. London: Faber, 2008

Miller, Liam. The Noble Drama of W.B. Yeats. Dublin: The Dolmen Press, 1977.

Mitchell, Donald. Britten \& Auden in the Thirties. Woodbridge: The Boydell Press, 2000.

Mitchell, Donald \& Philip Reed (eds.). Letters from a Life, The Selected Letters of Benjamin Britten and Diaries, Volume One, 1923-39. London: Faber, 1991.

Murray, Edmund. Noh Business. Berkeley: Atelos, 2005.

Reed, Philip, Mervyn Cooke \& Donald Mitchell (eds.) Letters from a Life, The Selected Letters of Benjamin Britten, 1952-1957, Volume Four. Woodbridge: The Boydell Press, 2008

Reed, Philip, \& Mervyn Cooke (eds.). Letters from a Life, The Selected Letters of Benjamin Britten, Volume Five, 1958-1965. Woodbridge: The Boydell Press in association with the Britten-Pears Foundation, 2010.

Reed, Philip, \& Mervyn Cooke (eds.). Letters From a Life, The Selected Letters of Benjamin Britten, 1966-1976, Volume 6. Woodbridge: The Boydell Press in association with the Britten-Pears Foundation, 2012.

Rupprecht, Philip. Britten's Musical Language. Cambridge: Cambridge University Press, 2001.

---. Rethinking Britten. Oxford: Oxford University Press, 2013.

Wiebe, Heather. Britten's Unquiet Pasts, Sound and Memory in Postwar Reconstruction. Music since 1900 Series. Cambridge: Cambridge University Press, 2012.

---. “Curlew River and Cultural Encounter". Philip Rupprecht (ed.). Oxford: Oxford University

Press, 2013. 156-180 


\section{NOTES}

1. As Plomer's libretto sometimes quotes verbatim from that translation, Faber included an acknowledgement of the play's 1955 authorised English translation published by the Japanese Classics Translation Committee in Tokyo in the Rehearsal Score (Reed and Cooke 580).

2. Once bitten, twice shy. Britten probably remembered the music critic Ernest Newman, then hostile to him, comparing Captain Vere's Act I muster in his 1951 Billy Budd with Captain Corcoran's in Gilbert \& Sullivan's ever popular, zany H.M.S. Pinafore.

3. Canticle II: Abraham and Isaac, op. 51, and Noye's Fludde, op. 59, resulted from his reading of Alfred W. Pollard's 1927 edition of English Miracle Plays, Moralities and Interludes: Specimens of the Pre-Elizabethan Drama and Hermann Deimling's edition of The Chester Plays. He also studied intensively the two volumes of Karl Young's The Drama of the Medieval Church (Reed and Cooke 134). Following the success of Noye Britten planned another children's opera he called the "Xmas piece" and put together a libretto derived from Herbert Deimling's edition of the Chester Miracle Plays (1892) but the project was shelved with the composition of the second Church Parable (Reed and Cooke 2012, 621).

4. The 1955 Aldeburgh Festival included a performance of 'The Second Shepherd's Play' from the Wakefield (or Towneley) Mystery. In 1960 Britten saw the Play of Daniel, a 1958 revival of the thirteenth-century liturgical drama from Beauvais by American producer Noah Greenberg. The performance he profoundly hated: "an object lesson in how not to do a mediaeval play" (Reed and Cooke 250-2, Wiebe 151-190).

5. For Auden's paramount influence on Britten, see Donald Mitchell, Britten \& Auden in the Thirties. Woodbridge: The Boydell Press, 2000

6. Britten set to music the poet's "Cradle Song for Elinor" in 1942, collaborated with MacNeice for three programmes as part of BBC-CBS series, Britain to America, between 1942 and 1943, and provided incidental music for MacNeice's Dark Tower, a radio play of 1945. (Kildea 2013, 216). Auden and MacNeice had travelled together in Iceland hence their 1937 poems, Letters from Iceland.

7. In his Introduction, perhaps thinking on his past experiences with Britten, MacNeice indicates sound radio as the medium very well able "to achieve the necessary suspension of disbelief and tempting one to experiment in modern morality plays or parable plays (MacNeice 9)."

8. Colin Graham had directed the first performance of Britten's Noye's Fludde in 1958 as well as designed its setting and was Director of Productions of Britten's English Opera Group from 1961 to 1975 . He later wrote the libretto for Britten's 1967 Golden Vanity.

9. "The Madwoman, an elderly noble woman, the Ferryman, a bluff but likeable character, the Traveller, an older, experienced and kindly man". (CRRS).

10. All Britten's alternative titles for the parable, "Across the river" or "Over the river" included the word "river".

11. "Zum Raum wird hier die Zeit», Richard Wagner. Parsifal. Paris, Aubier, Editions Montaigne, 1984 , p.98.

12. Britten's Thisbe in his 1960 Midsummer Night's Dream is associated with the flute which accompanies mad Lucia in Act III of Donizetti's opera, Lucia di Lammermoor.

13. The 'Screw' Theme that piles up a series of perfect fourths and opens, like an overture, the Governess's narrative in Britten's 1954 Turn of the Screw, Act I, scene 1, is a perfect example of the disquieting sound of that opera's fourth-based melodies.

14. A primitive form of heterophony, where two parallel plainchant melodic lines span consonant intervals like a fourth or a fifth.

15. "Come, Holy Ghost, Creator blest, And in our hearts take up Thy rest; Come with Thy grace and heavenly aid, To fill the hearts which Thou hast made.

o Comforter, to Thee we cry, Thou heavenly gift of God most high, Thou Fount of life, and Fire of 
love, And sweet anointing from above.

O Finger of the hand divine, The sevenfold gifts of grace are thine; True promise of the Father thou, who dost the tongue with power endow.

Thy light to every sense impart, And shed thy love in every heart; Thine own unfailing might supply to strengthen our infirmity.

Drive far away our ghostly foe, And thine abiding peace bestow; If thou be our preventing Guide, No evil can our steps betide.

Praise we the Father and the Son And Holy Spirit with them One; And may the Son on us bestow The gifts that from the Spirit flow.

V. Send forth Thy Spirit, and they shall be created.

R. And Thou shalt renew the face of the earth."

Britten first used the plainsong hymn for the prelude of his 1938 "religious cantata", The World of the Spirit, broadcast on BBC on Whit Sunday, which concludes with an extended setting of four of its verses in the English translation of poet Robert Bridges.

16. The Madwoman's costume never let the audience forget that it was being performed by a man and Pears was advised against performing the part lest he should be seen as a man in drag.

17. When Britten left for the US in May 1939, Franck Bridge, very much a father figure for Britten, presented him with his own viola.

18. The First Suite was first performed for the 1965 Aldeburgh Festival.

\section{ABSTRACTS}

Benjamin Britten defined himself as "a composer for an occasion" and some of his works are composed for commemorations and civic or religious ceremonies which conform to their own rituals. As an opera composer, a genre which stages rites and rituals and obeys to its own forms, Britten was very much aware of the necessity of ritual to which he wished to actively associate audience participation. The composer belonged to the Auden Generation and enjoyed a close relationship with the poet who believed in the concept of parable art. So it is no wonder that his Curlew River, his adaptation of the Noh play, Sumidagawa, should transfer the ritual of Japanese drama in a Fenland community of monks in pre-Conquest times and should be subtitled A parable for church performance. Partly based on the analysis of parable by his former associate, the poet Louis McNeice, this study will focus on Britten's integration of the genre's characteristics-its didactic intentions and references to prescriptive texts, the creation of a private world, the encounter with, and acceptance of the Other-to the rituals of operatic conventions and on the composer's universalist message which barely hides Britten's anxieties about the place of the artist and the alien in his time.

Benjamin Britten se définit comme un «musicien de circonstance » et certaines de ses œuvres sont composées pour des commémorations ou des cérémonies civiles ou religieuses qui obéissent à des rituels particuliers. Comme compositeur d'opéra, genre qui met en scène des rites et qui possède ses propres rites, Britten était sensible à la notion de rituel auquel il souhaite toujours associer la participation active du spectateur. Il appartient aussi à la "génération Auden », le poète, ami et mentor des années 1930, qui pratique l'art de la parabole. Aussi, il n'est guère surprenant qu'il donne à Curlew River (La Rivière au coulis), son adaptation de la pièce du théâtre No, Sumidagawa, qui transpose le rituel du drame japonais chez une communauté de moines des 
Fens anglais avant la conquête normande, le sous-titre de Parabole pour être jouée à l'église (Parable for church performance). Se fondant en partie sur l'analyse de l'art de la parabole par son contemporain et ancien collaborateur, le poète Louis McNeice, autre membre de la Génération Auden, cette étude se concentrera sur l'intégration des caractéristiques de la parabole -souci de pédagogie, appel à des textes prescripteurs, création d'un monde particulier, connaissance et accueil de l'Autre-, aux rituels de l'opéra et sur le message œcuménique du compositeur qui laisse cependant transparaître les inquiétudes de Britten sur la place de l'artiste et du déviant dans la société de son temps.

\section{INDEX}

Keywords: parable, ritual, Noh, narrative framework, plainsong, epilogue, madrigalism Mots-clés: parabole, rituel, Nô, cadre diégétique, plain-chant, épilogue, madrigalismes

\section{AUTHORS}

\section{GILLES COUDERC}

Maître de conférences

Université de Caen Normandie

gilles.couderc@unicaen.fr 